\title{
The constraints between amino acids influence the unequal distribution of codons and protein sequence evolution
}

\section{Yi Qian}

Southeast University Zhongda Hospital

\section{Rui Zhang}

Southeast University

\section{Xinglu Jiang}

southeast university

Guoqiu Wu ( $\nabla$ wgq@seu.edu.cn )

Southeast University Zhongda Hospital https://orcid.org/0000-0003-4581-0288

\section{Research}

Keywords: protein sequence evolution, codons, amino acid

Posted Date: June 9th, 2020

DOI: https://doi.org/10.21203/rs.3.rs-29954/v1

License: (a) (i) This work is licensed under a Creative Commons Attribution 4.0 International License. Read Full License

Version of Record: A version of this preprint was published at Royal Society Open Science on June 1st, 2021. See the published version at https://doi.org/10.1098/rsos.201852. 
Supplementary Materials Table S1 The characteristics of proteins in 33 species. 33 species were sorted by number of proteins(from 40725 to 517 ).

\begin{tabular}{|c|c|c|c|c|c|c|}
\hline Organisms & $\begin{array}{l}\text { Median total } \\
\text { length }(\mathrm{Mb})\end{array}$ & Median GC\% & $\begin{array}{l}\text { Number of } \\
\text { proteins }\end{array}$ & $\begin{array}{c}\text { Mean length } \\
\text { of proteins(aa) }\end{array}$ & $\begin{array}{l}<100 \text { aa of } \\
\text { proteins(\%) }\end{array}$ & $\begin{array}{l}>1000 \text { aa of } \\
\text { proteins(\%) }\end{array}$ \\
\hline Zea mays & 2067.62 & 46.82 & 40725 & $356.71(8-5101)$ & $12253(30.1)$ & $1006(2.5)$ \\
\hline Arabidopsis thaliana & 97.38 & 36.65 & 27142 & $398.74(16-5393)$ & $2309(8.5)$ & $1092(3.7)$ \\
\hline Danio rerio & 1391.74 & 36.9 & 25699 & $542.58(32-29256)$ & $577(2.1)$ & $2784(10.8)$ \\
\hline Pan troglodytes & 3021.76 & 41.8745 & 22251 & $499.78(24-8827)$ & $878(3.9)$ & $2054(9.2)$ \\
\hline Mus musculus & 2541.65 & 42.3 & 21736 & $471.47(25-34358)$ & $681(3.1)$ & $1684(7.7)$ \\
\hline Homo sapiens & 2994.61 & 41.3255 & 21560 & $477.30(24-14507)$ & $777(3.6)$ & $1749(8.1)$ \\
\hline Gorilla gorilla & 3035.66 & 41.332 & 21549 & $483.05(28-12739)$ & $1078(5.00)$ & $1910(8.86)$ \\
\hline Sus scrofa & 2508.91 & 42.226 & 21338 & $477.06(31-13288)$ & $626(2.9)$ & $1727(8.1)$ \\
\hline Chlorocebus sabaeus & 2789.66 & 40.9303 & 20771 & $532.96(23-14184)$ & $630(3.0)$ & $2178(10.5)$ \\
\hline Bos taurus & 2697.56 & 41.8776 & 20745 & $511.06(30-7569)$ & $594(2.86)$ & $2020(9.74)$ \\
\hline Ovis aries & 2615.52 & 42.4 & 19646 & $530.53(36-8974)$ & $477(2.4)$ & $2087(10.6)$ \\
\hline Gallus gallus & 1230.26 & 42.9197 & 14683 & $563.10(32-12010)$ & $357(2.4)$ & $1760(12.0)$ \\
\hline Serinus canaria & 1152.1 & 42.6 & 13632 & $585.50(28-34416)$ & $336(2.5)$ & $1801(13.2)$ \\
\hline Drosophila Melanogaster & 148.5 & 41.9402 & 13519 & $478.91(11-22949)$ & $913(6.8)$ & $1140(8.4)$ \\
\hline Saccharomyces cerevisiae & 12.3018 & 38.4253 & 5794 & 487.37(16-4910) & $322(5.6)$ & $481(8.3)$ \\
\hline Bacillus anthracis & 5.45 & 35.2 & 4764 & $262.84(26-5017)$ & $905(19.0)$ & $68(0.5)$ \\
\hline Pseudomonas aeruginosa & 6.57 & 66.2 & 4665 & $334.56(23-5627)$ & $308(6.6)$ & $63(1.4)$ \\
\hline Pseudomonas putida & 6.02 & 61.9 & 4366 & $338.08(23-8682)$ & $387(8.9)$ & $76(1.7)$ \\
\hline Escherichia coli & 5.17 & 50.6 & 4172 & $306.28(24-5291)$ & $572(13.7)$ & $68(1.6)$ \\
\hline Vibrio Parahaemolyticus & 5.11 & 45.3 & 4131 & $312.05(216084)$ & $584(14.1)$ & $65(1.6)$ \\
\hline Bordetella bronchiseptica & 5.2 & 68.2 & 3893 & $328.74(37-4218)$ & 203(5.2) & $28(1.1)$ \\
\hline Bacillus subtilis & 4.1 & 43.7 & 3629 & $292.15(25-5488)$ & $515(14.2)$ & $36(1.0)$ \\
\hline Salmonella enterica & 4.76 & 52.1 & 3384 & $316.48(13-3624)$ & $302(8.9)$ & $38(1.1)$ \\
\hline Vibrio cholerae & 4.02 & 47.5 & 2974 & $329.35(26-4555)$ & $261(8.8)$ & $43(1.4)$ \\
\hline Bordetella pertussis & 3.76 & 67.7 & 2868 & $326.41(37-4196)$ & $163(5.7)$ & $35(1.2)$ \\
\hline Pseudomonas syringae & 6.04 & 58.8 & 2773 & $350.31(36-13537)$ & 192(6.9) & $57(2.1)$ \\
\hline Staphylococcus aureus & 2.87 & 32.8 & 2354 & 284.58(29-9535) & $423(18)$ & $28(1.2)$ \\
\hline Staphylococcus epidermidis & 2.53 & 32 & 2106 & $286.57(25-9439)$ & $372(17.7)$ & $23(1.1)$ \\
\hline Streptococcus pneumoniae & 2.1 & 39.6 & 1467 & $315.28(38-2551)$ & $182(12.4)$ & $26(1.8)$ \\
\hline Streptococcus pyogenes & 1.83 & 38.5 & 1398 & $309.97(27-2045)$ & $159(11.4)$ & $18(1.3)$ \\
\hline Helicobacter pylori & 1.63 & 38.9 & 1142 & $332.98(30-2893)$ & $104(9.4)$ & $14(1.2)$ \\
\hline Chlamydia trachomatis & 1.05 & 41.2643 & 718 & $356.34(45-1786)$ & $53(7.4)$ & $21(2.9)$ \\
\hline Buchnera aphidicola & 0.64 & 25.6387 & 517 & $330.17(38-1407)$ & $40(7.7)$ & $6(1.2)$ \\
\hline
\end{tabular}



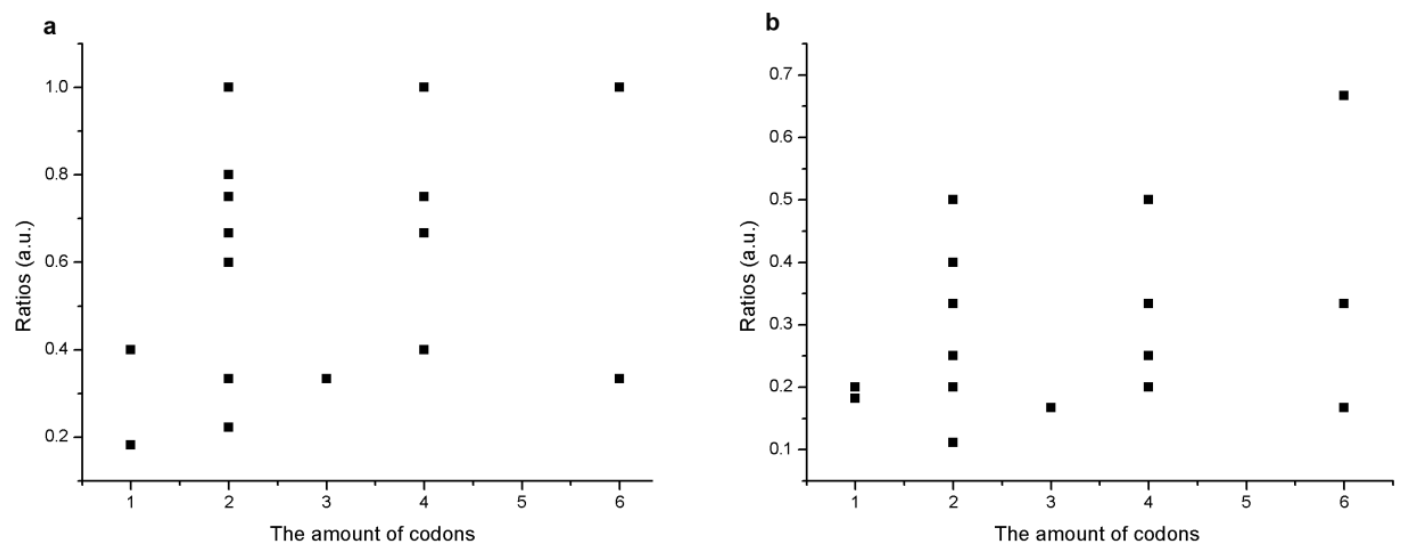

Supplementary MaterialsFigure S1 The relationships between the amount of codons and the O:C ratios and between the amount pf codons and the $\mathrm{N}: \mathrm{C}$ ratios. No correlation was observed unlike the amount pf codons and the $\mathrm{C}: \mathrm{H}$ ratios.
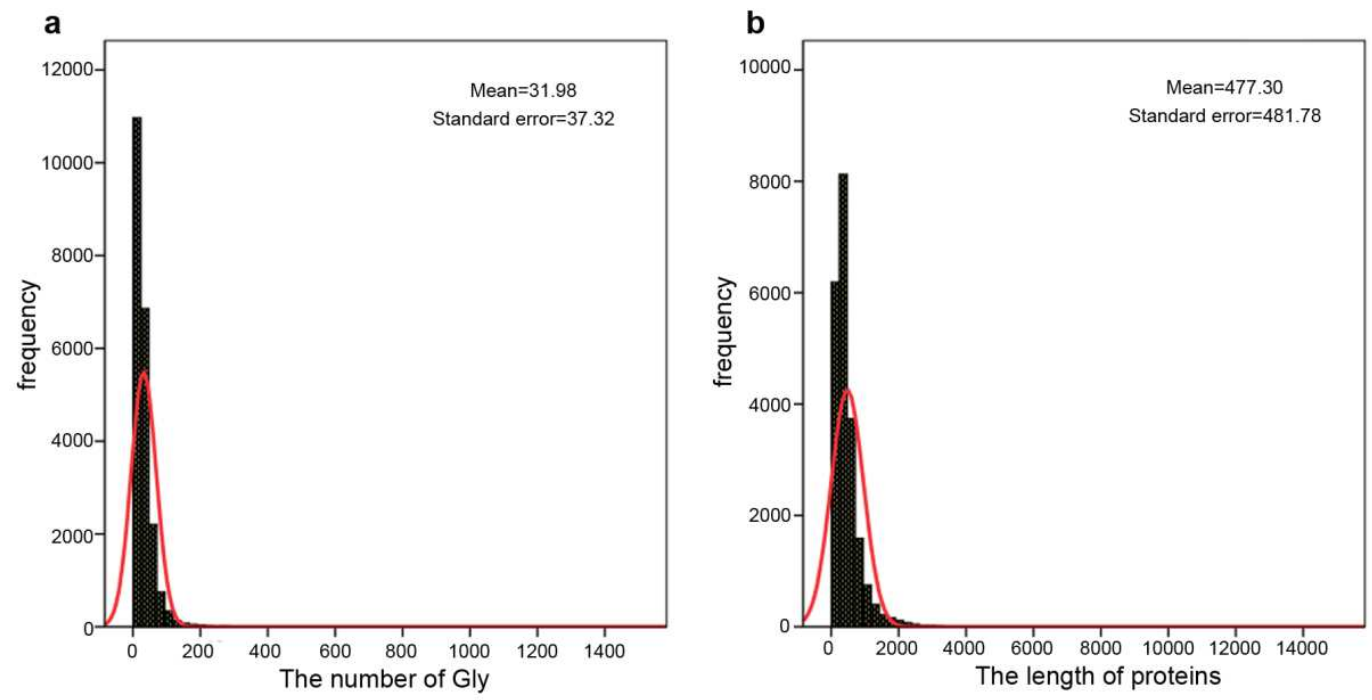

Supplementary Materials Figure S2 The frequency of the number of Gly and of the length of proteins in human. The number of Gly and of the length of proteins can not fit normal distribution $(\mathrm{Z}=30.43$ and $27.84, \mathrm{p}<0.000)$ and Poission distribution( $\mathrm{Z}=65.65$ and $88.25, \mathrm{p}<0.000$ ). The number of Gly was $31.98 \pm 37.32$ (from 0 to 1483) and the length of proteins was $477.30 \pm 481.78$ (from 24 to14507). 


\section{Figures}



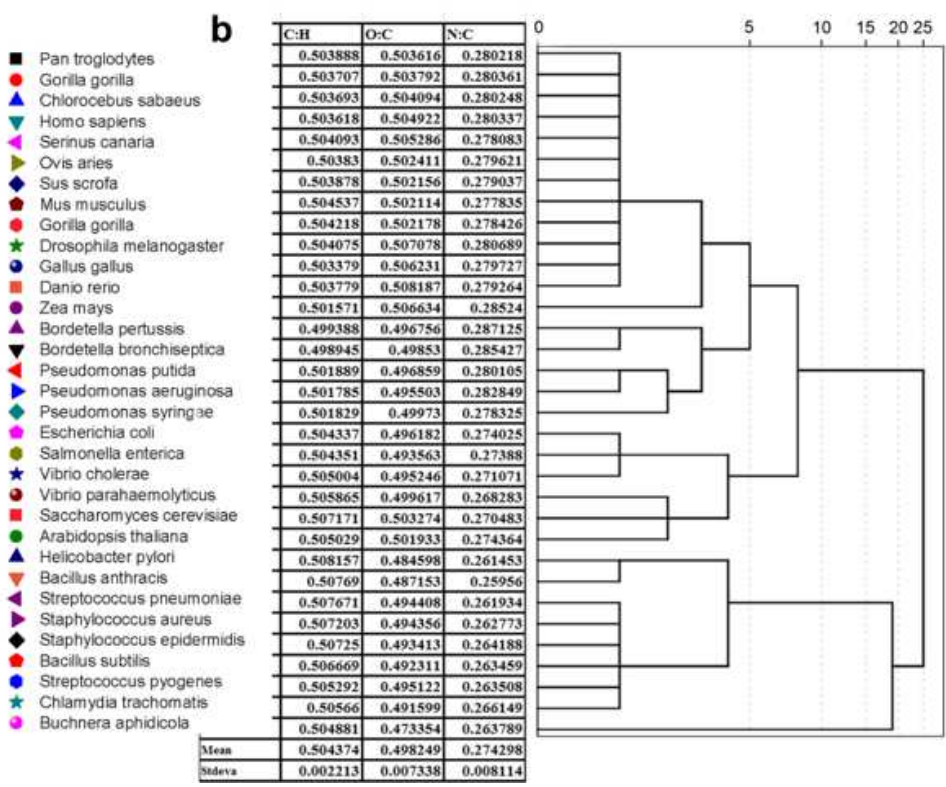

\section{Figure 1}

The mean of carbon and hydrogen ratios keep a relatively stable value $(0.50)$ in 33 species regardless of the significant change rates of 20 amino acids. a, Relationships between the sum of 20 amino acids of all proteins in 33 species and the number of their corresponding codons $\left(F=\left(n^{*} 61\right) /\left(N^{*} \mathrm{C}\right)-1\right), N$ : the sum of 20 amino acid in the genome of a species; $n$ : the number of one amino acid in the genome of a species; c:the number of their corresponding codons. 61 is the sum codons. b, the mean of carbon and hydrogen ratios $(0.50)$, oxygen and carbon ratios $(0.50)$, nitrogen and carbon ratios $(0.27)$ in 33 species. 
a

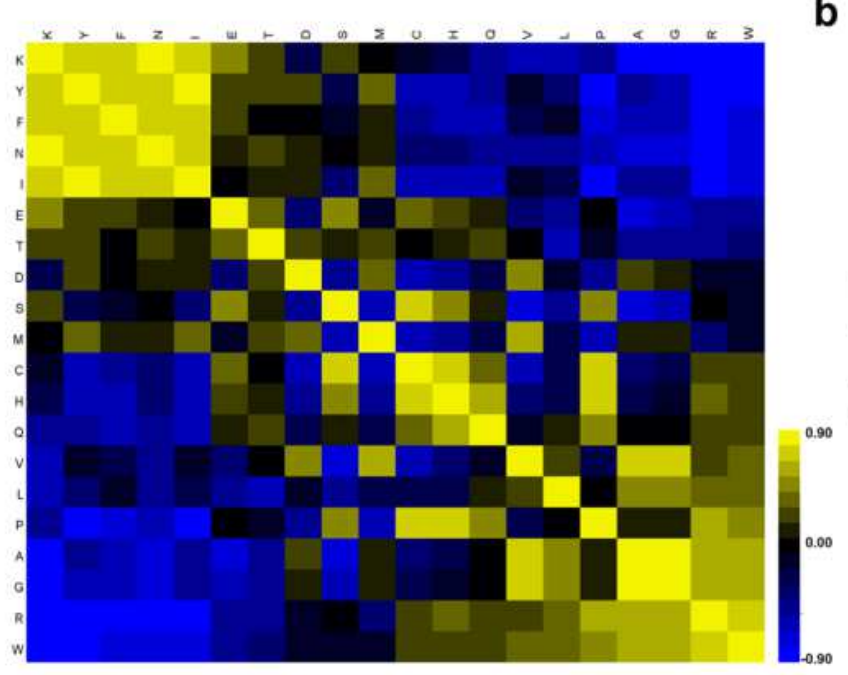

C

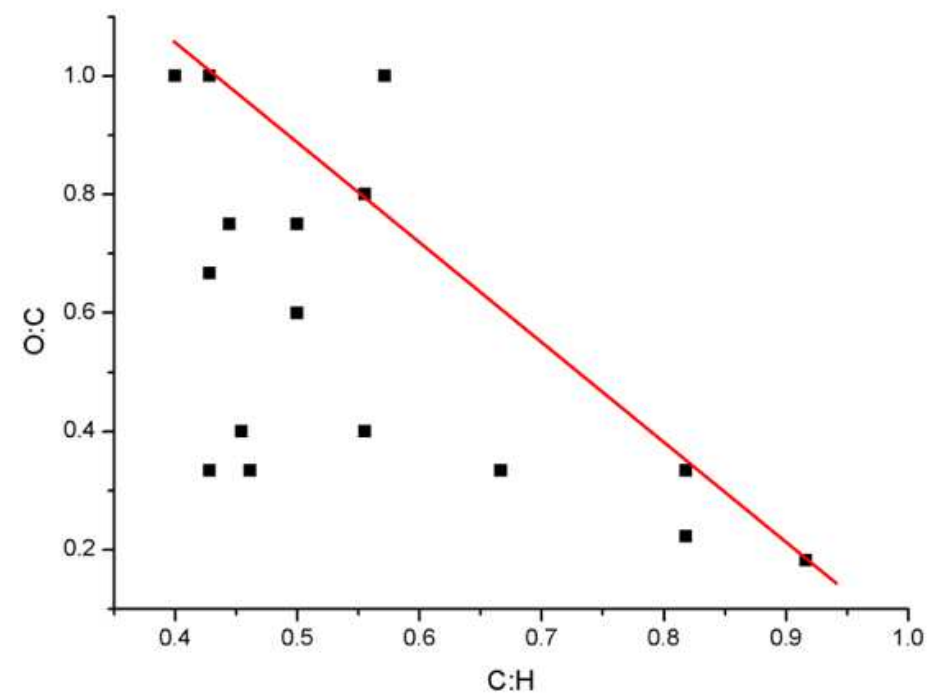

d b
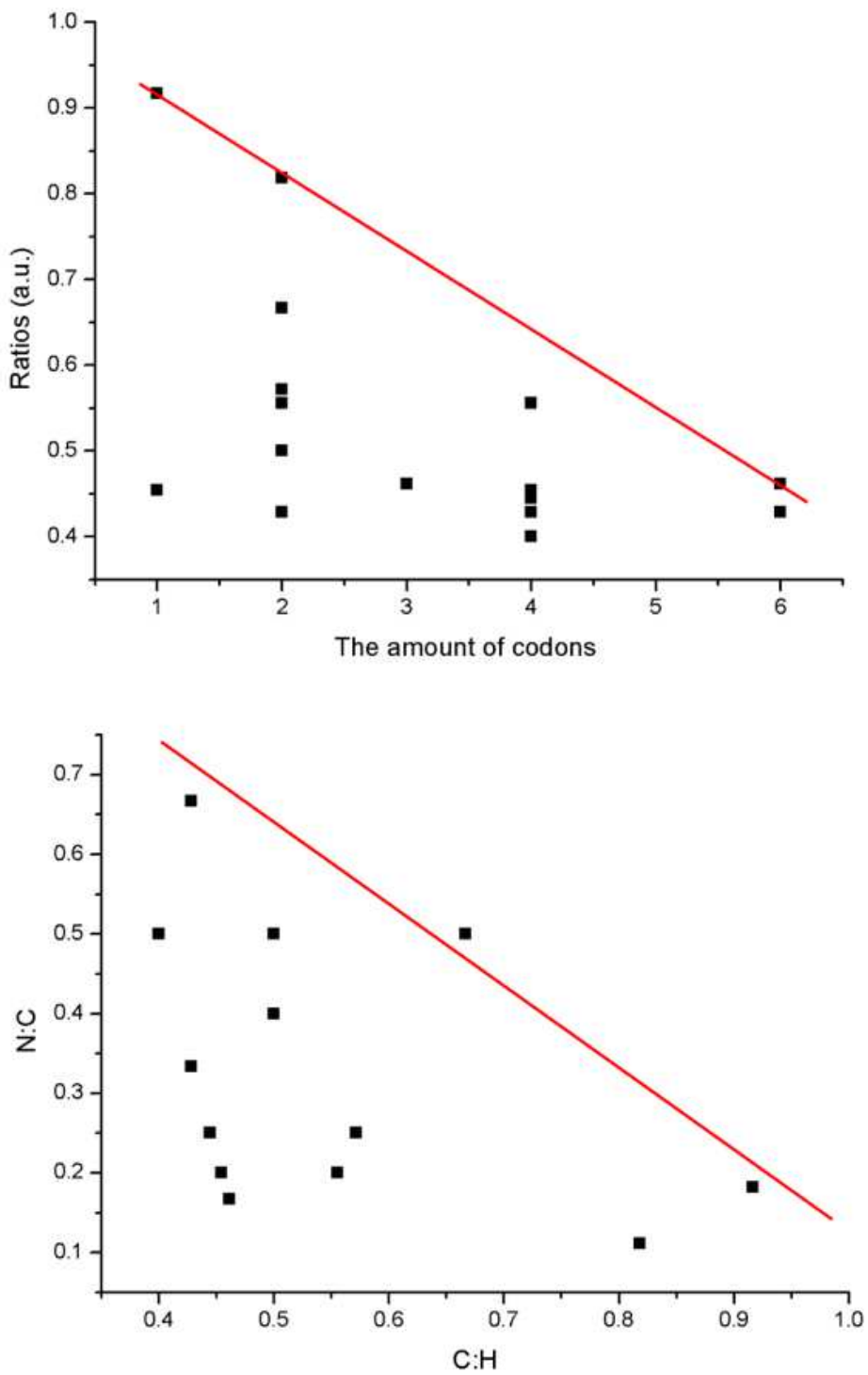

Figure 2

The reasons of the relatively stable mean of carbon and hydrogen ratios. Relationships between 20 amino acids in 33 species(a), between the amout of codons and C:H ratio in 20 amino acids (b), between O:C and $\mathrm{C}: \mathrm{H}$ ratio in 20 amino acids(c) and between $\mathrm{N}: \mathrm{C}$ and $\mathrm{C}: \mathrm{H}$ ratio in 20 amino acids (d).
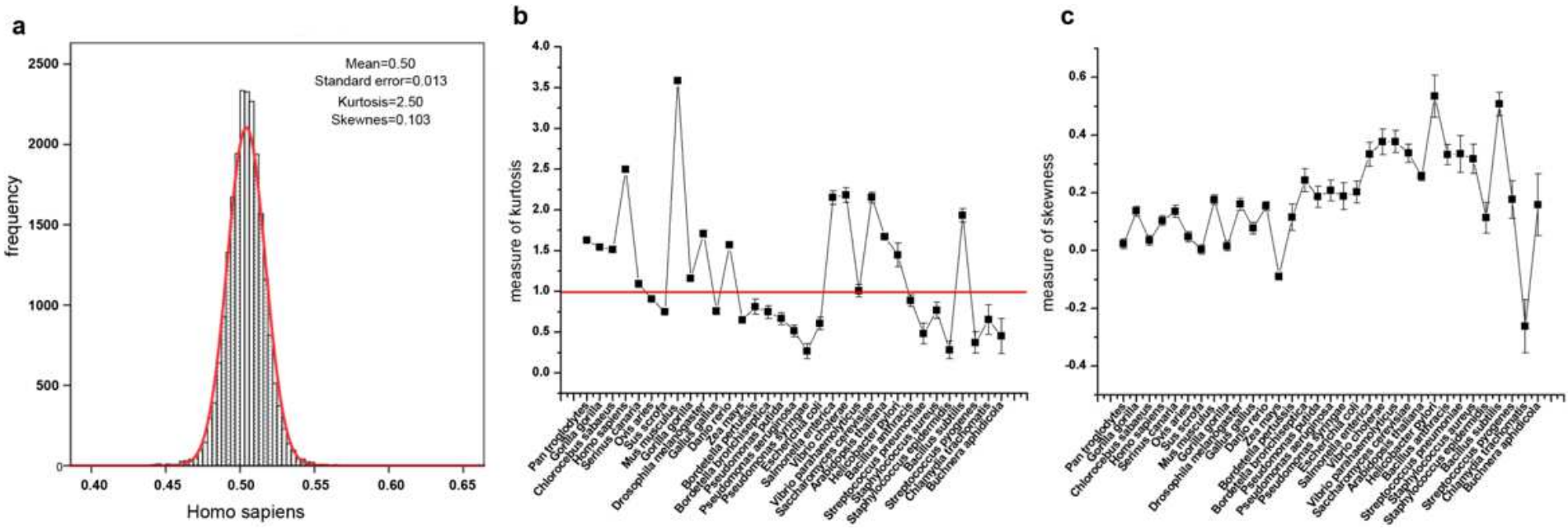


\section{Figure 3}

The carbon and hydrogen ratios of all protiens in 33 species were tend to 0.50 . a, The histogram of C:H ratio of 21560 proteins in homo sapiens(red line: normal curve); b, the kurtosis(red line: $y=1$ ) of the histogram of $\mathrm{C}: \mathrm{H}$ ratio of 33 species d; c, the skewness of the histogram of $\mathrm{C}: \mathrm{H}$ ratio of 33 species.



\section{Figure 4}

The interrelations between 20 amino acids in 33 speices. a-d, four kinds of scatter diagrams between in homo sapiens(positive correlation: $r>0.3, p<0.001$; negative correlation: $r<-0.3, p<0.001$; weak correlation: $|r|$ $<0.3, p<0.001$ and indifference correlation: $p>0.001) \rrbracket e$, Pearson correlation analysis between 20 amino acids in 33 spacies and 12540 correlation coefficient $(r, 19 \times 20 \times 33)$ were obtained and shown in the matrix, and a phylogenetic tree was below; $f$, one of the matrix(e): Pearson correlation analysis between Asp(D) and other 19 amino acids and the matrix of 627 correlation coefficient. 
a
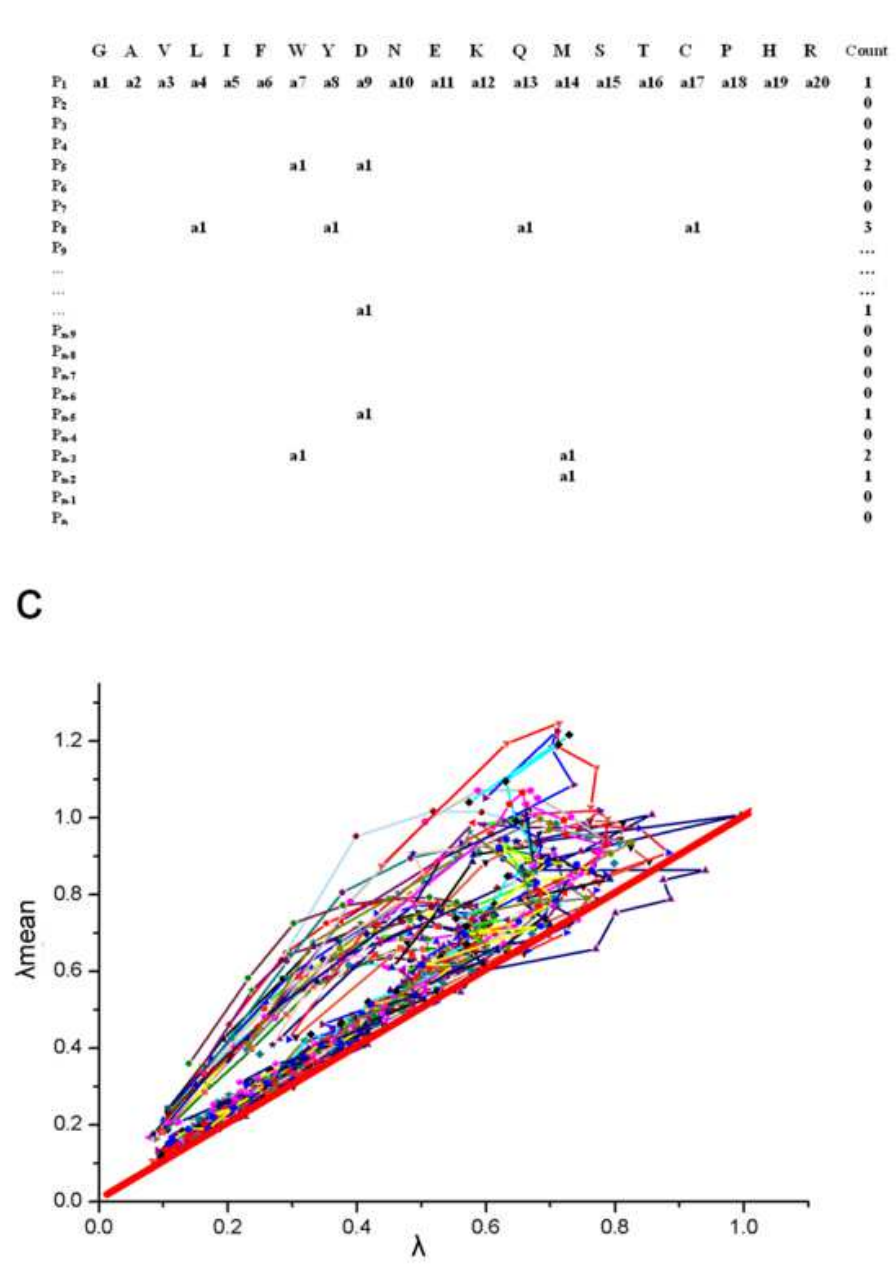

b



e



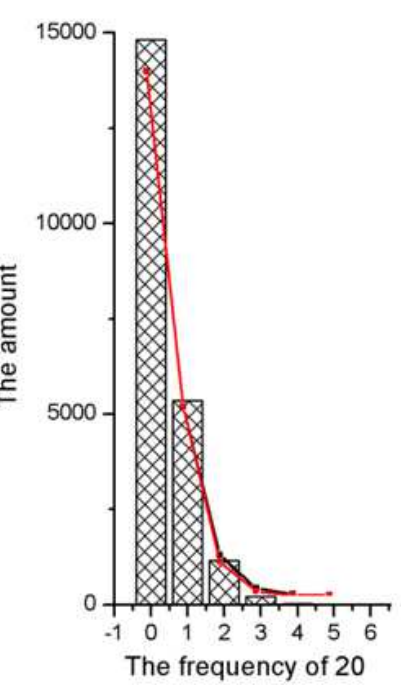

Figure 5

Poisson distribution. a, the model to count the frequency of the figures which is the number of 20 amino acids in a protein; $b$, the mean frequency of the figure( $\lambda$ mean) in 33 species, and the highest $\lambda$ mean was 4,5 or 6 in 33 species; $c$, the relationship between $\lambda$ mean and the theoretical frequency of the figures $(\lambda)$ when these figures would fit Poisson distribution, red line: $y=x$; $d$, the histogram of the frequency of 6 and 20 and their fitted curve under the conditions of $\lambda$ mean and $\lambda$.

\section{Supplementary Files}

This is a list of supplementary files associated with this preprint. Click to download.

- supplement1.pdf 